\title{
Fire Research at NBS*: The First 75 Years
}

\author{
DANIEL GROSS \\ Building and Fire Research Laboratory \\ National Institute of Standards and Technology \\ Gaithersburg, Maryland 20899, USA.
}

\begin{abstract}
A short history is presented of fire research and testing activities at the National Bureau of Standards from its beginnings in 1914 to 1989. Many of the principal technical projects undertaken to provide information needed by Government agencies, practicing architects and engineers, code officials and the general public are noted. Brief mention is made of organizational, staff and budget changes through the years. References to selected staff publications and source materials are cited.
\end{abstract}

KEYWORDS: detection; extinguishment; fire research; fire resistance; flammable fabrics; history; National Bureau of Standards; spontaneous combustion

\section{INTRODUCTION}

In a talk in 1983, Howard Emmons provided a retrospective view of the complete history of fire science by looking back from the year 2300 [1]. My objective is more traditional and restricted, looking backwards to a mere 75 -year period in the 20 th century; to the programs and accomplishments of a single government research laboratory; and to a time when many exciting breakthroughs were accomplished in other fields of science and technology which had little or no impact on the urgent societal problem of fire loss. This is an abbreviated story of fire research at the National Bureau of Standards from 1914 to 1989, only the last half of which involves the author's direct observations. Selected references will be provided to sources of historical information.

\section{BEGINNINGS (1914-1924)}

It has been reported that fire research actually started at NBS in 1904 when a pile of leaves on the Bureau grounds ignited and it was soon discovered that fire hoses from the different buildings could not be coupled together [2]. This coupling dilemma had occurred earlier in the same year with a much more disastrous result when a large area in Baltimore was destroyed by fire as fire departments from neighboring communities stood by helplessly, unable to connect their

* National Bureau of Standards was renamed National Institute of Standards and Technology in 1988. This article is a contribution of the US National Institute of Standards and Technology and is not subject to copyright. 
hoses to Baltimore's fire hydrants. The following year, the National Fire Protection Association (NFPA), with the active concurrence of NBS, adopted as a national standard a particular coupling together with an interchangeable device for nonstandard couplings.

Organized technical activities dealing with fire problems at the National Bureau of Standards started in 1914 with a Congressional authorization of $\$ 25,000$ for investigating the fire-resistant properties of building materials, plus $\$ 15,000$ for a research program. At that time, fires in the U.S. were claiming several thousand lives annually and property losses exceeded $\$ 250$ million, 10 times the rate of any country in Europe. In 1914, NBS hired a structural engineer, Simon Hansen Ingberg, and the following year a Fire Resistance section was established in the Heat Division with Ingberg in charge. Recognizing the national fire problem of frequent structural collapses and multi-building conflagrations, Ingberg focused on obtaining "fundamental engineering data to serve as a basis for the revision and reconstruction of state and municipal building codes". Under his leadership, NBS, Underwriters' Laboratories, Associated Factory Mutual Fire Insurance Companies, and the National Board of Fire Underwriters jointly sponsored a major study, from 1917 to 1920 at UL in Chicago, of the fire performance of building columns -- concrete, steel, masonry, wood and composite materials [3]. A parallel study on the fire endurance of a variety of concrete columns was conducted at the NBS Pittsburgh laboratories [4]. A large oil-fired wall furnace capable of accommodating specimens $16 \mathrm{ft}$ wide and $11 \mathrm{ft}$ high, was erected in the open on the NBS site and provided data on brick walls, loadbearing tile walls, gypsum partitions, gypsum-protected columns and treated and untreated wood partitions. Results from the more than 1000 fire endurance tests of this program provided architects, builders, code officials and insurance interests with the detailed high temperature material performance data previously unavailable [59]. From this work and earlier tests at Columbia University came the standard temperature-time exposure still used today. The classification and fire endurance rating of building construction elements for building code purposes had been established.

During the initial 10-year period, it appears that the maximum number of staff working directly on fire-related projects never exceeded six or seven, although other NBS organizational units and staff were an essential part of the interdisciplinary program. By 1924, permanent staff included Nolan D. Mitchell, Harry D. Foster and W.A. Hull (the latter at the NBS Pittsburgh laboratory). During this period, the Fire Resistance Section was also involved in special projects, including investigation of and advice concerning fires in Government buildings, fire performance of products (e.g. theater curtains, insulated safes) and review and advice on building fire safety regulations such as building exits codes.

\section{DIVERSIFICATION (1925-1947)}

In the early 1920 s, additional studies were carried out on columns and on insulated safes and cabinets for record protection. Loads of up to $700,000 \mathrm{lbs}$ could be applied in the testing of columns. The wall furnace was moved to a new building in 1930, converted to gas and fitted to permit application of structural loads up to $35,000 \mathrm{lbs}$. The following year, in cooperation with the American Institute of Steel Construction, a "temporary" 13.5 by $18 \mathrm{ft}$ furnace was constructed for the testing of welded-steel floor assemblies then being considered for use in the largest skyscrapers. Applied loads of up to $60,000 \mathrm{lbs}(240 \mathrm{psf})$ were achieved using pig iron weights. Following completion of a 16-test series [10] involving fire exposures from above as well as below, the furnace continued to serve as a productive piece of test equipment until 1950 when replaced by a more modern 13.5 by $18 \mathrm{ft}$ floor furnace with a hydraulic loading capacity of $60,000 \mathrm{lbs}$. The testing of structural members comprised a major activity for over 50 years. 
In 1924, the first direct appropriation was made for construction of an "experimental structure" specifically designed for fire growth or "burnout" studies. Over the years, this 16 by $30 \mathrm{ft}$ building, a larger one 30 by $60 \mathrm{ft}$, and several smaller brick buildings were used to collect detailed information on the intensity and duration of fires in office, storage and residential compartments containing typical furnishings. Tests were also conducted in actual buildings scheduled for demolition, the most notable being an old 5-story building in downtown Washington in 1928, in an area being cleared for construction of the Federal Triangle. The spectacular collapse of this building (Fig. 1) convinced city officials to ban further experimentation in the downtown area. Ingberg's landmark 1928 article relating the severity of fire with the magnitude of the combustible contents or "fire load" [11], still forms the underlying basis for the building code requirements which are prescribed in terms of hourly ratings according to the standard

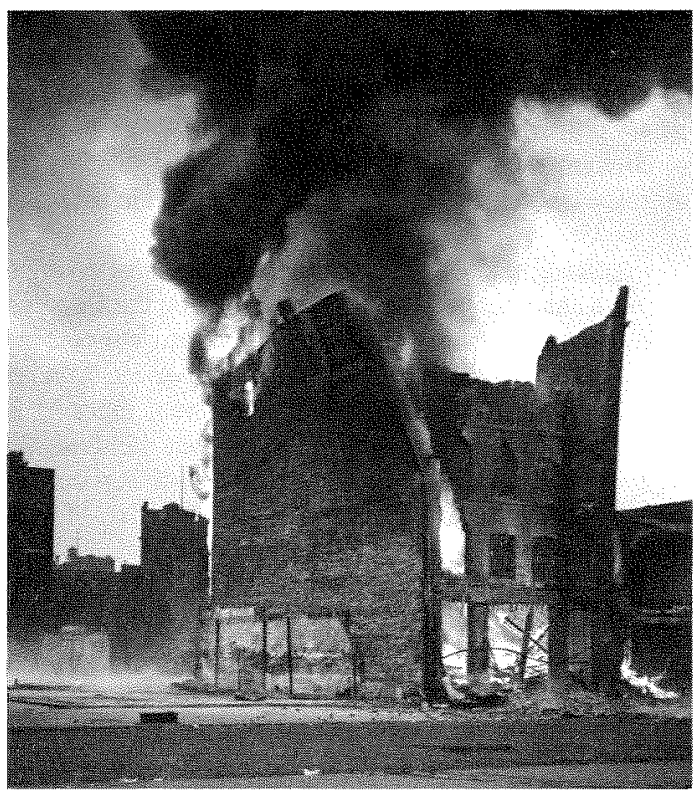

Figure 1 Wall collapse during experimental burnout test, Wash. DC 1928. fire endurance test exposure. The large amount of information on fire loads, fire endurance ratings and building codes available in 1942 was assembled by an interagency group and published as "BMS 92", one of the most referenced and important fire publications [12]. This also provided the basis for interpolation and extrapolation of fire endurance data by building code officials.

During the twenties and thirties, the work of the Fire Resistance section was broadened to encompass self-heating and ignition studies, performance of detection devices, fire extinguishment systems using water and carbon dioxide, cigarettes as a cause of fire (mattresses, forest fires,etc),

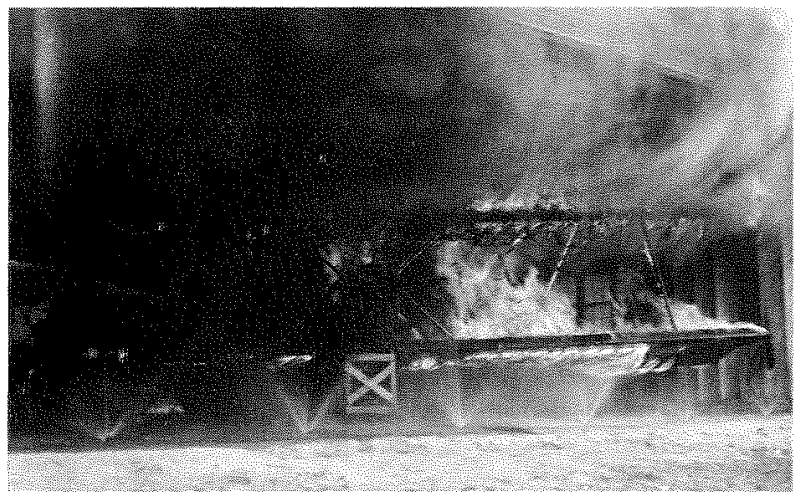

Figure 2 Sprinkler protection of aircraft hangar at NBS, 1928. chimney fires, performance of paints, coatings and roof coverings, fire load surveys, and more. Fire research activities at NBS have traditionally concentrated on the effects of fires in buildings but other fire problems were also studied. One area involved fire studies of materials and equipment used aboard ships, both passenger and military. One notable example during this period was the shipboard fire compartmentation studies on the S.S. Nantasket in cooperation with the U.S. Coast Guard and the Society of Naval Architects 
and Marine Engineers [13]. Another area involves fire safety of aircraft, both in-flight and on the ground. An interesting example was the experimental study of the use of floor-mounted sprinkler systems to control fires in aircraft hangars, a study made easier because of the availability of a newly constructed hangar at the Bureau's Washington site (Fig.2). The need for conducting other studies involving aircraft fire problems led ultimately to the establishment of the Civil Aeronautics Administration Flight Test Center at Indianapolis.

Although the Fire Resistance Section was involved in occasional testing of the "ignition points" of materials and products for many years, the impetus for systematic study of ignition did not start until problems and unresolved questions concerning spontaneous heating and ignition became persistent in the late 1920s. In November 1929, in response to recommendations by the National Fire Protection Association at its annual meeting earlier in the year, a special conference on Spontaneous Heating and Ignition was held in Washington, cosponsored by NFPA with the cooperation of the U.S. Departments of Agriculture and Commerce. At this 2-day meeting, a general discussion was held with the objective of outlining the growing problem of fire losses due to spontaneous heating of agricultural and industrial products, and developing a coordinated program of fundamental research. At that time, it was estimated that between 8 to 10 percent of the total national fire loss was attributable to spontaneous ignition, even though one Department of Agriculture scientist stated that he started his investigations convinced that there was no such thing. Among the products which resulted in considerable fire loss originating from spontaneous heating were: hay, grass, grains, seeds, jute and other natural fibers, coal, charcoal, animal and vegetable oils, wood chips and sawdust, cotton, rubber and pyroxylin plastics.

At the meeting, Ingberg described the NBS work on spontaneous heating and emphasized its close relationship to the definition and determination of ignition temperature [14]. This is due to the fact that self-ignition of a material only occurs when the rate of internal heat generation (due to oxidation, depolymerization, or biological reactions) exceeds the rate at which heat is lost by radiation, convection and conduction to the surroundings at its (critical) temperature. Most of the NBS work was initiated by and supported by outside sponsors and involved studies on materials such as celluloid and $x$-ray film, the latter involved in the 1929 Cleveland Clinic fire [16]; cordage fibers like jute involved in fires during marine transport; and a variety of other materials submitted by the Army, Navy, and Post Office Departments. In the succeeding three decades, considerably more research was conducted with the goal of defining the nature of spontaneous heating as well as the temperatures and environmental factors necessary for ignition of solids, liquids and gases. In 1934, C.R. Brown completed a very detailed experimental study of factors affecting the ignition temperatures of solid materials [15]. Later, the size of the material sample was found to be critically important to the exothermic self-heating reaction and this was subsequently confirmed both experimentally and analytically by application of steady-state and transient models of thermal explosion. It thus became clear that the self-ignition temperature was not a unique constant but was a decreasing function of size, and for a given external ambient temperature, a minimum or "critical" size was necessary for self-ignition [16].

Through the years, NBS studied a wide variety of materials using different test equipment and techniques, including the original Mackey apparatus, hot plates, oven tests, isothermal and adiabatic calorimeters, thermal analysis, etc. Among the materials studied were: pure chemicals; agricultural products; wood and plastic products; coals; natural and synthetic oils; natural and synthetic rubbers and foams; cordage fibers; explosives and propellants; and more. P.C.Bowes in his comprehensive book entitled "Self-heating: Evaluating and Controlling the Hazard" mentioned that the article by Mitchell set the scene for the application of a thermal explosion model for the prediction of self-ignition from simple experiments. This reference should be consulted for indepth analysis of the thermal basis for what was originally considered a very perplexing mystery - the spontaneous heating problem. 
Although Ingberg and his staff were being called upon to analyze a greater number and variety of fire problems, direct Government funding was very limited and Ingberg was able to undertake special programs only by encouraging industry and other-agency sponsorship. Even as late as 1935, the direct project appropriation for investigation of fire resisting properties was less than $\$ 20,000$ out of a total NBS appropriation of $\$ 2.0$ million. Through about 1935 , the number of staff never exceeded 10 or 12, although several industry-supported Research Associates helped to supplement the permanent staff. Research Associates were provided by organizations such as the Common Brick Manufacturers Association to support the long-term project on fire endurance of brick walls, and the Marine Fire Underwriters, to look into the problems of fires in the storage of jute fiber.

\section{BUILDING TECHNOLOGY (1947-1973)}

For many years, the technical work associated with buildings had been carried on in several divisions of NBS. In 1947, a Building Technology Division was formed at NBS by bringing together, from other divisions, smaller organizational units concerned with structural engineering; fire research; heat transfer and mechanical systems; wall, floor and roof coverings; and codes and standards. The Chief of the Division was Douglas Parsons who had been Chief of the Division of Clay and Silicate Products. When Ingberg reached the mandatory retirement age of 70 that year, he was succeeded as Chief of the now renamed Fire Protection Section by Nolan D. Mitchell who had been with the Fire Resistance Section since 1923. Even in retirement, Ingberg remained very active for another 20 years, working on flammability measurements in his garage and preparing and publishing at least half a dozen articles which were based on his earlier NBS work but which had remained unpublished because of on-the-job time constraints. A notable example was the comprehensive report on brick walls [17] which tied together test results dating back over 30 years. Five years later, Mitchell would also retire to be succeeded in September 1952 by A. F. Robertson.

Shortly after joining the section in early 1950 , Robertson presented a talk to the Division in which he provided a suggested research program intended to provide a better understanding of ignition, fire spread, containment, detection and extinguishment. Supplementing the basic research was a perceived need for development of new methods of test and this became a prime activity along with standard testing performed for Government agency sponsors with occasional field testing for verification and validation. NBS performed standard tests of products for the requesing Government agency and received reimbursement from the agency, but normally did not provide testing services directly for commercial clients. During the 1950 s, the only commercial laboratory equipped to perform fire endurance tests, Underwriters' Laboratories, became overloaded resulting in a backup of several years at one point. Here, NBS was able to assist by performing commercial fire endurance testing under the provision that "other facilities were not available". Another means used by industry groups to facilitate needed technical studies at NBS was through a funding arrangement with the National Research Council. Over a period of many years, starting in the 1920 s and extending through the $1950 \mathrm{~s}$, such funds were used to finance both research projects and salaries for NRC-hired staff working at NBS. Results of such studies were always made public and available to all segments of the construction industry.

One research project involved measuring the self-ignition properties of combustible liquids. Considerable divergence existed in values of the ignition temperature reported by different investigators, due principally to differences in the concepts of the property and in the methods for its determination. N.P. Setchkin showed that the size and insulation of the ignition flask were significant factors and proposed a standardized measurement technique [18].

In 1952, the Fire Protection Section was able to assist the U.K. Fire Research Station in its study of the effect of scale size on the fire endurance of prestressed concrete beams. Since the FRS furnace could only accommodate $12 \mathrm{ft}$ long beams, it was not possible to test a full-scale 20 
$\mathrm{ft}$ long beam, and since our furnace was $18 \mathrm{ft}$ long, the longer beams were sent to NBS for test. Dennis Lawson, Director of FRS witnessed the NBS tests which followed the U.K. test method. One of the test findings was that the large beams tested at NBS spalled whereas the smaller beams tested at FRS did not. The British solved the problem by adding steel reinforcement mesh in the concrete cover of the beam.

An investigation into the effects of variations in ceiling construction on the fire endurance of floor-ceiling assemblies [19] pointed up the lack of a specific definition of structural failure, i.e. the time at which the test assembly fails to sustain the applied load. In a very concise and straightforward way, Ryan and Robertson provided an analysis and a simple load failure criterion for floors and beams based on both a limiting deflection and a limiting rate of deflection [20]. Although not generally adopted in the U.S., these criteria are recognized and used fairly widely elsewhere.

It is worth noting that NBS staff have actively participated in national standardization organizations, notably NFPA and ASTM, from the beginning. There have also been contacts, cooperation and participation through the years with research and standardization organizations world-wide, including the British Fire Prevention Committee (as early as 1915), ISO, CIB, Combustion Institute, IAFSS, and the many other national and international organizations involved in fire research, testing and standardization.

In 1950, the full time permanent staff was approximately 15 with an annual budget of approximately $\$ 100 \mathrm{~K}$. During a period of expanding staff and more sponsors, a number of more diverse projects were undertaken. One involved the test of fire growth within a full-size stateroom prior to construction of the superliner S.S. United States [21]. The worst-case scenario assumed that three young women travelling together to Europe would spread all their clothes and other personal effects in disarray in their cabin and that a fire ensued following accidental spilling of whiskey and leakage of a can of combustible cleaning fluid. The first few attempts to get the contents of a waste paper basket to ignite with a lighted cigarette were unsuccessful which leaves one to wonder why brandy was not chosen instead, especially considering the Section's knowledge of the properties of combustible liquids.

Another project dealt with the fire hazard of nitrocellulose photographic film decomposing in storage vaults. Although the manufacture of nitrocellulose film was discontinued in 1950 and replaced with cellulose acetate "safety" film, large quantities of this type of film containing important information of a historical or record nature were stored throughout the U.S. Unfortunately, nitrocellulose is very easily ignited, is subject to selfheating and self-ignition [22], burns vigorously even under water using its own chemically combined oxygen, and represents an explosion hazard in storage. Using a vault representative of actual storage located in a secluded area in Beltsville, MD, NBS scientists determined vent sizes, overpressure levels, the

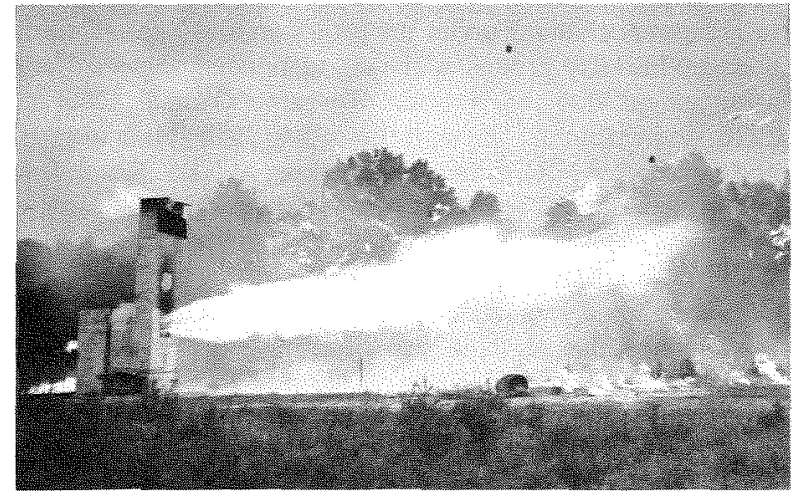

Figure 3 Flames projecting 150ft in film vault tests, 1949. 
effectiveness of detectors and sprinklers, and other design variables for film vaults and film storage containers (Fig 3).

At one time, NBS performed standardized type testing on all portable fire extinguishers listed and approved by the U.S. Coast Guard. In another project, a series of small standard fires and typical use conditions were selected to provide a merit rating for hand-held extinguishers (vaporizing liquid, foam, carbon dioxide and dry chemical) for use aboard recreational motorboats [24]. Among other things, the results showed that carbon tetrachloride extinguishers were only marginally effective while at the same time their use was known to present a potential inhalation toxicity hazard to individuals. As a result, such extinguishers were banned for use by the Federal Government and subsequently for use on railroads, on trucks, and then by individual states. A project sponsored by the U.S. Navy Bureau of Ships addressed the basic question of the mechanism of fire extinguishment by dry powder extinguishers [25]. It was found that sodium bicarbonate used in such devices did not extinguish by breaking down into carbon dioxide as had been postulated, but in fact much of the powder remained intact after application. This led to the use of other chemicals, notably potassium bicarbonate, as well as silica and talc to see to what extent the effect was caused by radiation shielding, by excluding oxygen, or by cutting off the fuel supply. It was subsequently determined that a chain-breaking reaction was a significant operating mechanism. Later in the early 1960s, Mr. E.C. Creitz found that halogens released by extinguishing agents would recombine the previously decomposed oxygen molecules so that such chemical extinguishing agents were especially effective, and also that halogenated inhibitors such as methyl bromide were much more effective on the air rather than on the fuel side of the reaction [26].

NBS not only provided such research and testing assistance directly to Government agencies upon request, but also helped agencies in establishing their own testing and research laboratories by providing advice and personnel training. Among the agencies and groups benefitting from NBS assistance in setting up laboratories were: Federal Trade Commission (fabric testing); Federal Aviation Administration (NAFEC labs); U.S. Coast Guard (Mobile Bay facility); National Research Council of Canada (Ottawa); and the Factory Mutual Research Corporation, following a five-year Research Associate Program at NBS (1965-1969).

Another project dealt with ignition from high intensity thermal radiation and was sponsored by Armed Forces Special Weapons Project (AFSWP) for the Department of Defense. Since it was originally a classified project, some of its findings were never fully reported but several basic research techniques and findings, e.g. the development of the adiabatic furnace [27] and the importance of thermal inertia on ignition and flame spread [28] were notable offsprings of this project. Another formerly classified project involved an inexpensive device for recording the location of an atmospheric atomic bomb blast. This extremely simple gadget contained no lenses or mirrors, only a graduated cardboard grid behind a pin-hole aperture on which a scorch mark would form to identify the altitude and direction of the blast. This project was sponsored by the Office of Civil Defense (OCD) and field measurements were taken in the summer of 1957. However, no final report was ever written when the sponsor failed to provide the funding needed for data analysis and report writing.

In 1955, the National Research Council/NAS organized a Committee on Fire Research following a request by the Office of Civil and Defense Mobilization (OCDM) and the U.S. Forest Service. This broad-based Committee attempted to integrate and expand fire research activities and to make more people aware of the gaps in our knowledge about fire. The original emphasis was on the mass fire problem although NBS scientists emphasized the need to address the basic urban fire problem. One important activity of the Committee on Fire Research was to sponsor conferences in which past and future problems and research activities could be freely discussed. 
NBS staff made significant contributions at conferences held in 1956, 1957, 1959 and 1961, with increasing participation by fire scientists around the world.

In 1955, the decision was made to move NBS from its site in the residential area of upper Northwest Washington, D.C. to Gaithersburg, Maryland. Ryan and Robertson worked up plans for the new facilities, suitable for a staff of 100. Since the architect's initial estimate was 6 to 8 times the proposed budget, and since the entire NBS budget had also been exceeded, NBS Director Astin decided to separate out the Fire Facilities portion and to include in a later supplemental appropriation request. In 1961, a specially appointed committee set up by the President's Science Advisor reported the need for NBS to take a lead role in fire research but without interfering with fire activities which came under the jurisdiction of other Government Departments. Also, that funds to support grants and contracts should be made available to NBS. Over the years, these grantees performed research reported in a total of over 20 publications.

Through the years, NBS staff have made some major contributions in the fields of fire detection and extinguishment. In one specialized study in the early 1950s, C.S. McCamy studied the problem of detecting fires in aircraft engine nacelle spaces and identified the radiation emitted in five selected wave-bands from the ultraviolet to the far infrared [29]. He proposed a detector based on the unique flickering characteristics of accidental hydrocarbon fuel flames and a sudden increase in radiance for detection. The most far-reaching influence of CFR in the detection area was the demonstration of the effectiveness of residential single-station detectors in the early 1970 s combined with improvements in reliability. Following the displacement of over 25,000 residents in southern Pennsylvania due to Hurricane Agnes in 1971, the Department of Housing and Urban Development (HUD) quickly made available 13,000 mobile homes. Since fire losses in mobile homes was three times greater than in conventional residences, R.G. Bright of the NBS staff encouraged HUD to require single-station smoke detectors meeting prescribed specifications to be installed. This extended the recommended use of such detectors in residences built by HUD under the special Operation Breakthrough Program and provided a stimulus for further improvements and economies in mass production. It is of interest to note that in 1971, nationwide production of these devices was approximately 50,000 and that this rose to 12 to 14 million in 1977 at which time a recognized national standard (UL 217) for residential smoke detectors based in large part on technical studies at NBS had been adopted. NBS also pioneered the promotion of light hazard sprinkler systems for residential systems, in part by conducting necessary research and in part by engineering evaluations and demonstrations [30,31].

Flammability of textiles and textile products was addressed over several decades. Early publications on flameproofing of cotton and rayon fabrics, including formulas for nondurable treatments, served as important reference sources for years $[32,33]$. Large loss-of-life fires in the Coconut Grove nightclub (Boston) and a circus tent (Hartford, Conn.) prompted several voluntary standards and Government specifications with NBS input. For at least two decades, NBS tested samples of the "Big Top" each year before the circus opened in Washington,D.C. Following fire injuries involving children's "cowboy chaps" in 1944 and "torch sweaters" in 1952, a voluntary standard was completed in December 1952 with the aid of Marjorie W. Sandholzer, a Fire Section chemist. This was the standard on which Congress based the Flammable Fabrics Act, signed into law in June 1953. Clothing and interior furnishing fires continued and the Act was amended in 1967 to authorize DOC to set mandatory standards, HEW to investigate such fires and the Federal Trade Commission to oversee enforcement. Jim Ryan, on detail to Commerce, provided the technical rationale establishing the need for legislation. Returning to NBS, he headed a new Fabric Flammability Section to provide technical support. Mandatory standards were set for carpets and rugs, mattresses, and children's sleepwear. Of interest, Consumers Union provided flammability test data on both carpets and blankets, but voluntary action by the blanket industry removed the questionable fabrics so no mandatory standard was developed. A recent article credited the 
children's sleepwear standard with reducing annual deaths to less than five [34]. The Act creating the new Consumer Products Safety Commission transferred to the Commission responsibility for the Flammable Fabrics Act and NBS continued to provide CPSC with technical support for several years.

Another and more far reaching piece of legislation to affect fire research at NBS was the Fire Research and Safety Act (FRSA) of 1968 (PL 90-259). Title I of the FRSA expanded the research, education and training programs at NBS, and Title II established the National Commission on Fire Prevention and Control. The technical data and rationale that convinced Congress of the need for the legislation was also organized by Ryan. NBS was now authorized to investigate fire accident causes and to develop national statistics; to develop fire prevention and fire control measures; to support education, training, safety and effectiveness of firefighters; all in addition to broad research and engineering programs. In 1968, Mr. Irwin Benjamin became the fourth Chief of the Fire Research Section, and Dr. Robertson and Dr. Rockett were assigned critical planning roles in the Office of Fire Technology of the NBS Institute for Applied Technology, where they developed a report outlining the responsibilities and functions of an expanded fire program. During the next 10 years, the extent of the NBS fire program was considerably broadened and the staff expanded by a factor of 3 to accommodate the newer work.

\section{LEGISLATIVE MANDATES AND EXPANSION (1973-1989)}

In 1973, the National Commission on Fire Prevention and Control transmitted its final report "America Burning" to President Nixon. It included 90 recommendations that the Commission believed would reduce death, injuries and property losses from fire by $50 \%$ in the next generation. The principal recommendations relating most directly to the NBS activities were that (a) NBS and the National Science Foundation (NSF) sponsor research dealing with fire prevention, fire fighting and fire service needs and operations, (b) NBS and NIH develop standards dealing with combustion toxicology, (c) NBS develop programs to translate research results into engineering principles, and (d) NBS develop guidelines for a systems approach to fire safety.

Anticipating Congressional legislation in response to the recommendations being formulated by the Commission, NBS in January 1972 established an Office of Fire Programs, headed by Dr. G.K. Walters. Included within this program was the Office of Flammable Fabrics which had been established in 1970 with J.E. Clark as Chief. Later in 1972, Walters left and Clark became head of the Fire Technology Division. In early 1974, Dr.John W. Lyons, a research chemist from Monsanto Corporation, with a strong interest in the chemistry of fire, took over leadership of the fire program, pulling together into one unit the several existing fire-related NBS programs. After considerable debate, the Federal Fire Prevention and Control Act of 1974 (Public Law 93-498) became law in October 1974, calling for a Center for Fire Research to be established at NBS with a separate budget authorization. The law authorized funding maximums of $\$ 3.5$ million for FY 1975 and $\$ 4.0$ million for FY 1976. CFR now consisted of a broadened in-house program as well as a significant program of University grants and contracts incorporating the fire research grants program of NSF.

In 1973, the Federal Trade Commission proposed a class action complaint alleging that certain plastics products used in construction and furnishing of buildings and homes may constitute serious fire hazards. The proposed complaint cited 26 producers and marketers of cellular polyurethane and polystyrene, SPI (the plastics industry trade association), and ASTM (the national standardssetting organization). This culminated in a very pronounced effect on fire research activities at NBS for years to come. At the core of the problem was the use of terms such as "nonburning" and "self-extinguishing" as determined in small-scale laboratory tests versus the performance of products in "real fire scenarios". To resolve the legal dilemma, the plastics industry initiated a 5- 
year, 5 million dollar research program consisting of 26 major project grants of which two were assigned to NBS, along with a total of 12 plastics industry Research Associates. The combined total project effort at NBS represented close to $\$ 1$ million. The Products Research Committee (PRC), composed of members of the plastics manufacturing industry, academia and Government, was chaired by Dr. Lyons. At its termination in 1979, the PRC grantees had published approximately 50 journal articles plus numerous reports and several University theses [35].

The staff expansion which began in the late sixties continued through the seventies in order to accommodate the broader scope of work. In 1974, the full-time staff reached 90 from a total of slightly less than 30 in 1970. That year also marked the end of NBS use of the Washington test facilities and a shift in emphasis. The program included major projects on basic research, combustion product toxicity, fire safety in mobile homes, fire growth computer modeling, fire safety evaluation systems, analysis of fire risk, detection and extinguishment, and further fire test method development. New areas included human behavior in fire, arson and equipment for firefighters.

The 1970's began the most fruitful period of research into the basic processes underlying the initiation and spread of fire. This included combustion chemistry, ionic processes in flames, mechanisms of retardants, aerosol mechanics, smoldering vapor phase absorption of radiation, etc. Particularly for basic research, the grants program provided valuable resources at many Universities to supplement the NBS activities.

In the area of fire toxicology, the Center actively pursued the development of a standardized screening test for measuring the inhalation toxicity of combustion products. This study, which involved the first use of laboratory animals at NBS combined with chemical analysis, was aimed at identifying materials and manufactured products which could generate combustion products of unusual toxicity.

Analysis of mobile home fire statistics has led CFR to take an active part in laboratory studies of fire growth in such residences. With sponsorship by HUD over a 4-year period (1975-1979), CFR was able to identify several areas of needed improvement and to provide this specialized industry with useful information and advice during its period of greatest expansion. The principal CFR recommendations related to improved protection in the kitchen range area where cooking fires are likely, and to flame spread limitations for the wall and ceiling materials throughout the mobile home, since interior finish surfaces could serve as means for rapid flame spread [36].

CFR made a special effort to collect and analyze fire statistics in order to pinpoint ways to reduce particularly serious fire losses. A pioneering study by Clarke and Ottoson [37] analyzed the characteristics of the major fire death scenarios involved in residential fire deaths. This was followed by predictive analyses of intervention strategies associated with fire deaths and injuries involving cigarettes on mattresses, carpets, and upholstered furniture [38] and formed the basis for the CPSC-mandated requirements in these areas. Such analyses included laboratory studies an example of which is the extensive evaluation of the burning characteristics of upholstered furniture [39]. Also provided were decision and cost-benefit analyses for detectors, for sprinklers and for combined detector/sprinkler alternatives in residences [40].

In 1979 when Dr. Lyons moved up to head the NBS National Engineering Laboratory, Dr. F.B. Clarke assumed leadership of CFR and continued until 1981 when he joined Irwin Benjamin to form a private consulting firm. Since November 1981, Dr. Jack E. Snell has directed a Center whose staff size has remained fairly steady at about 80 with an average appropriated budget of approximately $\$ 5.6$ million. Through the 1980 s, the Center has place major emphasis on computer modeling of fire growth while maintaining recognition of the need for experimental validation. 
Modeling of selective aspects of the heat transfer and fluid flow processes involved in fire has been a research activity through the years at NBS. This included electrical analog modeling of heat conduction [41] reduced scale modeling of the burning of geometrically-scaled wood cribs [42] as well as fire growth in reduced-scale enclosures [43], salt water modeling of fluid flow [44], and various aspects of mathematical modeling. With the advent of the high speed computer, as well as the accumulated knowledge of basic properties and process functions, it became possible to start predictive modeling of fire growth in compartments by combining the interacting chemical, thermal and fluid flow processes. In the 1970s, zone models involving a collection of coupled process equations began to be developed, notably at NBS and at Harvard University through an NBS grant. Basic CFR contributions in this field include the modeling of: quasi-steady flow in an enclosure $[45,46]$, contribution of the combustible contents [47,48], estimation of safe egress time [49], smoke movement in high-rise buildings [50], and fire growth in multiple compartments [51,52]. An advanced zone model, designated FAST (fire and smoke transport) [53], has been used widely and has been incorporated into an overall "hazard" model which combines models for the movement of occupants and their tolerance to toxic combustion products, with models of fire growth and smoke generation [54]. More complete modeling of the fluid mechanics, heat transfer and combustion processes is possible by solving the appropriate conservation equations over time and space with appropriate boundary conditions, and significant CFR contributions to "field modeling" have been made [55].

CFR continued its applied research projects providing information necessary for the practicing fire protection specialists, architects, builders and code officials. Included among the new areas addressed more recently are fire growth in mines, fire safety of wood-burning stoves [56], and oil spill and offshore platform fires [57,58]. A Fire Investigation Handbook was also prepared as a reference tool for on-scene fire investigators [59].

Building code officials have the unenviable task of enforcing mandatory building code requirements which often appear to be a collection of rigid and sometimes conflicting specifications. Building architects and design engineers claim they are stifled in their attempts to employ independent design solutions. In an attempt to clarify the basis for the code requirements and to permit alternative design solutions meeting the intent of the fire safety provisions of the code, H.E. Nelson and other CFR staffers developed the Fire Safety Evaluation System approach. This consists of an organized matrix of fire safety components, including construction, interior finish, smoke control, detection, sprinklers, etc. evaluated with reference to three functional safety parameters (containment, extinguishment and people movement) and assigned numerical values of importance. The assigned values are based in part on technical knowledge of the effectiveness of design features and protective measures and in part on expert judgment. By combining the numerical values in a prescribed way, it is possible to obtain a safety score for each complete design approach considered to meet the intent of a given code. In addition, each facility is rated according to occupancy risk, which takes into account the number, age and mobility of occupants as well as the availability of trained staff. This was done initially for institutional health care facilities as prescribed in the 1973 NFPA Life Safety Code and subsequently for a variety of other types of occupancies [60-64]. It may be used for upgrading existing buildings as well as for comparing alternative new designs, thereby permitting building designers and code officials to achieve an equivalent level of safety often at lower cost. In one study, the estimated cost of retrofitting a major hospital was reduced from $\$ 11$ million to $\$ 2$ million by application of the method [65].

CFR has been involved in laboratory test method development and improvement over its entire history. Some of the established standard test methods in which NBS has played a major role include tests for fire endurance of structural components, "noncombustibility", radiant panel, smoke density chamber, floor coverings, full scale room tests, ignition and flame spread, heat 
release ("cone") calorimeter, cigarette ignition of upholstered furniture, blankets [66a-j], potential heat, flame-resistant textiles [67a,b], children's sleepwear, carpets and mattresses [68a,b,c]. Several of these test methods, the essence of which were conceived or developed at NBS have reached the point of acceptance and standardization at the international level.

Today CFR continues to pursue a wide range of basic and applied fire research as well as important standards activities geared to today's more complex fire problems and the challenges of tomorrow. Thus continues an effort which may have had its roots in an accidental fire on the NBS grounds in 1904.

\section{ACKNOWLEDGEMENTS}

My task was made considerably easier by utilizing unpublished historical summaries prepared by Alex Robertson and Harry Shoub. Reference was also made to the transcript of an oral history interview held at NBS on August 3, 1988 with contributions by Alex Robertson, Harry Shoub, Carroll Creitz, Marjorie Sandholzer, Bill Bailey, Jim Ryan and the author. The following source materials provide additional historical material:

Cochrane, R.C., Measures for Progress, A History of the National Bureau of Standards, U.S. Department of Commerce, 1966.

Achenbach, P.R., "Building Research at the National Bureau of Standards", Building Science Series 0, October 1970.

Gallegher, N.,(editor), "Building Research at the National Bureau of Standards 1968-1974", BSS 75, March 1979.

Robertson, A.F., "Simon H. Ingberg -- NBS Pioneer in Fire Research", ASTM Standardization News, 13:2, 50-53, 1985.

Reeves, M.V. "The Federal Role in Local Fire Protection". Advisory Commission on Intergovernmental Relations, Report A-85, October 1980.

\section{REFERENCES}

1. Emmons, H.W. "Further History of Fire Science", Combustion Science and Technology, 40, 167-174, 1984.

2. Kushner, L.M. "The NBS and the Fire Research and Safety Act of 1968", Fire Journal, : 62: 5, 32-33,118, 1968.

3. Ingberg, S.H., Griffin, H.K., Robinson, W.C. and Wilson, R.E., "Fire'Tests of Building Columns", NBS Technical Paper 184, 1921.

4. Hull, W.G. and Ingberg, S.H. "Fire Resistance of Concrete Columns", NBS Technologic Papers No. 272, 1925.

5. Ingberg, S.H. "Fire Tests of Brick Walls", Clay-Worker, 83, 234, 1925.

6. Ingberg, S.H. and Foster, H.D. "Fire Resistance of Hollow Load-Bearing Wall Tile", NBS J. Research, 2, 1, 1929.

7. Ingberg, S.H. "The Fire Resistance of Gypsum Partitions", Proc.ASTM, 25, part II, 299, 1925.

8. Mitchell, N.D. "Fire Tests of Columns Protected with Gypsum" NBS J. Research, 10, 737, 1933.

9. Brown, C.R. "Fire Tests of Treated and Untreated Wood Partitions", NBS J. Research 220 , $217,1938$.

10. Shoub, H.' and Ingberg, S.H. "Fire Resistance of Steel Deck Floor Assemblies", NBS Building Science Series 11, 1967.

11. Ingberg, S.H. "Tests of the Severity of Fires", Quarterly NFPA, 22, 43-61, 1928.

12. ...., "Fire Resistance Classifications of Building Constructions, NBS Buildings Materials and Structures BMS 92, 1942. 
13. -..-, "Fire Tests on the Steamship Nantasket", Trans. SNAME, 45, 253-363, 1937.

14. Ingberg, S.H. "Research at the National Bureau of Standards on Spontaneous Heating and Ignition", in Report of Conference on Spontaneous Heating and Ignition of Agricultural and Industrial Products, U.S. Department of Agriculture, 1930.

15. Brown, C.R. "Determination of the Ignition Temperatures of Solid Materials", NFPA Quarterly, 28: 2, 1984.

16. Mitchell, N.D. New Light on Self Ignition", Quarterly NFPA, 45, 165, 1951.

17. Ingberg, S.H. "Fire Tests of Brick Walls", BMS 143, 1954.

18. Setchkin, N.P. "Self-Ignition Temperatures of Combustible Liquids", NBS J. Research, 53 : $1,49,1954$.

19. Ryan, J.V. and Bender, E.W. "Fire Endurance of Open-Web Steel-Joist Floors With Concrete Slabs and Gypsum Ceilings", NBS BMS 141, 1954.

20. Ryan, J.V. and Robertson, A.F. "Proposed Criteria for Defining Load Failure of Beams, Floors, and Roof Constructions During Fire Tests", NBS J. Research, 63C, 2, 1959.

21. McComb, A.H. and Benzenberg, E.E. "Stateroom Fire Test", Trans.SNAME, 58, 567-607, 1950.

22. Cummings, J.W., Hutton, A.C. and Silfin, H. "Spontaneous Ignition of Decomposing Cellulose Nitrate Film", J. Soc. Motion Picture and Television Engineers, 54, 268, 1950.

23. Ryan, J.V., Cummings, J.W. and Hutton, A.C. "Fire Effects and Fire Control in Nitrocellulose Photographic Film Storage", NBS BMS 145, 1956.

24. Shoub, H., Lee, T.G. and Cameron, J.M. "Methods of Testing Small Fire Extinguishers", NBS BMS 150, 1957.

25. McCamy, C.S., Lee, T.G. and Shoub, H. "Fire Extinguishment by Means of Dry Powder", Sixth Symposium (International) on Combustion, 795-801, 1956.

26. Creitz, E.C. "Inhibition of Diffusion Flames by Methyl Bromide and Trifluoromethyl Bromide Applied to the Fuel and Oxygen Sides of the Reaction Zone", NBS J. Research, 65A, 4, 1961.

27. Raskin, W.H. and Robertson, A.F. "An Adiabatic Apparatus for the Study of Self-Heating of Poorly Conducting Materials", Review of Scientific Instruments, 25: 6, 541-544, 1954.

28. Gross, D. and Loftus, J.J. "Surface Flame Propagation on Cellulosic Materials Exposed to Thermal Radiation", NBS J. Research, 67C: 3, 251-258, 1963.

29. McCamy, C.S. "A Five-Band Recording Spectroradiometer", NBS J. Research, 56: 5, 293, 1956.

30. Hayes, W.D. Jr. and Zile, R.H., "Full-Scale Study of the Effect of Pendent and Sidewall Location on the Activation Time of An Automatic Sprinkler", NBSIR 82-2521, 1982.

31. Ruegg, R.T. and Fuller, S.K., "A Benefit-Cost Model of Residential Fire Sprinkler Systems", NBS Technical Note 1203, 1984.

32. -.--, NBS Letter Circular LC 467, 1936.

33. Sandholzer, M.W. "Flameproofing of Textiles", NBS Circular C455, 1946.

34. Harwood, B. and Hall, J.R.Jr., "What Kills in Fire: Smoke Inhalation or Burns?", Fire Journal, 29-34, 1989.

35. -.--, Fire Research on Cellular Plastics: The Final Report of the Products Research Committee", 213 pp, PRC, 1980.

36. Budnick, E.K. and Klein, D.P., "Mobile Home Fire Studies: Summary and Recommendations", NBSIR 79-1720, March 1979.

37. Clarke, F.B. and Ottoson, J., "Fire Death Scenarios and Firesafety Planning", Fire Journal, 70: 3, 20-22; 117-118, 1976.

38. Helzer, S.G., Offensend, F.L., Buchbinder, B., "Decision Analysis of Strategies for Reducing Upholstered Furniture Fire Losses", Final Report, NBS TN 1101; 155 pp. June 1979.

39. Babrauskas, V., Krasny, J.F, "Fire Behavior of Upholstered Furniture", NBS Monograph 173: $101 \mathrm{pp}$. November 1985. 
40. Gomberg, A., Buchbinder, B. and Offensend, R.L., "Evaluating Alternative Strategies for Reducing Residential Fire Loss-The Fire Loss Model", NBSIR 82-2551, August 1982.

41. Robertson, A.F. and Gross, D. "An Electrical-Analog Method for Transient Heat-Flow Analysis", NBS J. Research, 61: 2, 105, 1958.

42. Gross, D. "Experiments on the Burning of Wood Cribs", NBS J. Research, 66C: 2, 99-105, 1962.

43. Gross, D. and Robertson, A.F. "Experimental Fires in Enclosures", Tenth Symposium (International) on Combustion, 931-942, 1965.

44. Steckler, K.D., Baum, H.R. and Quintiere, J.G. "Salt Water Modeling of Fire Induced Flows in Multi-Compartment Enclosures", 21st Symposium (International) on Combustion, 143-149, 1986.

45. Rockett, J.A. "Fire Induced Flow in an Enclosure", Combustion Science and Technology, $12,165,1976$.

46. Quintiere, J.G. "Growth of Fire in Building Compartments", in Fire Standards and Safety, ed. A.F. Robertson, pp. 131-167, ASTM STP 614, 1977.

47. Quintiere, J.G. and McCaffrey, B.J. "The Burning of Wood and Plastic Cribs in an Enclosure: Vol 1", NBSIR 80-2054, 1980.

48. Rockett, J.A "Modeling of NBS Mattress Tests with the Harvard Mark IV Fire Simulation", Fire and Materials, $\underline{6}, 80,1980$.

49. Cooper, L.Y. "A Mathematical Model for Estimating Available Safe Egress Time in Fires", Fire and Materials, 6, 135, 1982.

50. Klote, J. and Fothergill, J.W. Jr., "Design of Smoke Control Systems for Buildings", NBS Handbook 141, 1983.

51. Tanaka, T. "A Model of Multiroom Fire Spread", Fire Science and Technology, 3, 105, 1986.

52. Rockett, J.A. and Morita, M. "The NBS/Harvard VI Multiroom Fire Simulation", Fire Science and Technology, 5:2,159, 1985.

53. Jones, W.W., "Model for the Transport of Fire, Smoke and Toxic Gases (FAST)", NBSIR 84-2934, 1985.

54. Bukowski, R.W., Peacock, R.D., Jones, W.W. and Forney, G.L. "HAZARD I: Fire Hazard Assessment Method", NIST Handbook 146, 1989.

55. Baum, H.R., Rehm, R.G. and Mulholland, G.W., "Prediction of Heat and Smoke Movement in Enclosure Fires", Fire Safety Journal, 6: 3, 193-201, 1983.

56. Peacock, R.D., "NBS Activities in Wood-Heating Safety", Proceedings Wood Heating Alliance, 85-86, National Bureau of Standards, Gaithersburg, MD, 1982

57. Evans, D.D., Mulholland, G.W., Gross, D., Baum, H.R., Walton, W.D. and Saito, K., "Burning, Smoke Production, and Smoke Dispersion From Oil Spill Combustion", NBSIR 89-4091, October 1989.

58. Evans, D.D., "Wellhead Fire Suppression With Water Sprays", Proceedings U.S. Dept. of the Interior in Technology Assessment and Research Program for Offshore Minerals Operations, OCS Study MMS-86-0057, Gregory, J.B., and Smith, C.E. Editors,165-168, 1988.

59. Brannigan, F.L., Bright, R.G. and Jason, N.H., "Fire Investigation Handbook", NBS Handbook 134, 197 pp, August 1980.

60. Nelson, H.E. and Shibe, A.J., "System for Fire Safety Evaluation of Health Care Facilities", NBSIR 78-1555-1, 1980.

61. Nelson, H.E., Levin. B.M., Shibe, A.J., Groner, N.E., Paulsen, R.L., Alvord, D.M. and Thorne, S.D., "Fire Safety Evaluation Systems for Board and Care Homes", Final Report, NBSIR 83-2659. March 1983.

62. Nelson, H.E. and Shibe, A.J., "System for Fire Safety Evaluation for Multifamily Housing", Interim Report, NBSIR 82-2562, September 1982. 
63. Nelson, H.E. and Shibe, A.J., "Development of a Fire Evaluation System for Detention and Correctional Occupancies", NBSIR 84-2976, January 1985.

64. Nelson, H.E., Shibe, A.J., Levin, B.M., Thorne, S.D. and Cooper, L.Y., "Fire Safety Evaluation System for National Park Service Overnight Accommodations", NBSIR 84-2896, September 1984.

65. Chapman, R.E., "Cost-Conscious Guide to Fire Safety in Health Care Facilities", NBSIR 82-2600, November 1982.

66. Annual Book of ASTM Standards, Volume 04.07, ASTM Philadelphia, PA 19103

a. ASTM E119 "Test Methods for Fire Tests of Building Construction and Materials"

b. ASTM E136 "Test Method for Behavior of Materials in a Vertical Tube Furnace at $750 C^{\prime \prime}$

c. ASTM E162 "Test Method for Surface Flammability of Materials Using a Radiant Heat Energy Source"

d. ASTM E648 "Test Method for Specific Optical Density of Smoke Generated by Solid Materials"

e. ASTM E648 "Test Method for Critical Radiant Flux of Floor-Covering Systems Using a Radiant Heat Energy Source"

f. ASTM E603 "Guide for Room Fire Experiments"

g. ASTM E1321 "Test Method for Determining Material Ignition and Flame Spread Properties"

h. ASTM E1354 "Test Method for Heat and Visible Smoke Release Rates for Materials and Products Using an Oxygen Consumption Calorimeter"

i. ASTM E1352 "Test Method for Cigarette Ignition Resistance of Mock-Up Upholstered Furniture Assemblies"

j. ASTM D4151 "Test Method for Flammability of Blankets"

67. National Fire Codes, National Fire Protection Association, Quincy, MA 02269

a. NFPA 259 "Test Method for Potential Heat of Building Materials"

b. NFPA 701 "Flame-Resistant Textiles and Films"

68. a. CFR 1615; CFR 1616 "Standard for the Flammability of Children's Sleepwear", Consumer Product Safety Commission, Bethesda, MD 20816

b. CFR 1630; CFR 1631 "Standard for the Surface Flammability of Carpets and Rugs"

c. CFR 1632 "Standard for the Flammability of Mattresses (and Mattress Pads)" 
